\title{
Implementation of protocol for reception with risk classification in an obstetric emergency unit
}

\author{
Implementação do protocolo de acolhimento com classificação de risco em uma emergência \\ obstétrica
}

Amanda de Freitas Brilhante ${ }^{1}$, Camila Teixeira Moreira Vasconcelos ${ }^{1}$, Raylla Araújo Bezerra ${ }^{1}$, Sâmua Kelen Mendes de Lima ${ }^{1}$, Régia Christina Moura Barbosa Castro ${ }^{1}$, Ana Fátima Carvalho Fernandes ${ }^{1}$

\begin{abstract}
Objective: to evaluate the implementation of reception with risk classification. Methods: evaluative study with a sample of 736 instruments for risk classification in a reference service. Results: authors identified greater search for care by pregnant women in the third trimester of pregnancy, being the pain and vaginal bleeding the main complaints. There was also a significant number of patients seeking care out of the period of pregnancy and childbirth. As risk classification, there was prevalence of the green color and the waiting time of 51 minutes. Conclusion: the clientele seeking gynecological and obstetric care in primary care needs further information about the signs and symptoms that characterize emergency care, because there has been great unnecessary demand for the service and the lack of training of professionals from the obstetric emergency unit led to waiting time above the recommended by the Brazilian Ministry of Health.
\end{abstract}

Descriptors: User Embracement; Obstetrics; Emergencies.

Objetivo: avaliar a implementação do Acolhimento com Classificação de Risco. Métodos: estudo avaliativo com amostra de 736 instrumentos para classificação de risco, em um serviço de referência. Resultados: identificou-se busca maior por atendimento de mulheres gestantes no terceiro trimestre, sendo a dor e o sangramento vaginal as principais queixas. Verificou-se também o número significativo de pacientes que procuraram o atendimento fora do ciclo gravídico-puerperal. Como classificação de risco, prevaleceu a cor verde e o tempo de espera de 51 minutos. Conclusão: a clientela que busca atendimento ginecológico e obstétrico precisa ser melhor informada na atenção básica sobre os sinais e sintomas que caracterizam emergência e urgência, pois a grande procura pelo serviço de forma desnecessária e a falta de treinamento dos profissionais da própria emergência obstétrica acarretou tempo de espera acima do preconizado pelo Ministério da Saúde do Brasil.

Descritores: Acolhimento; Obstetrícia; Emergências.

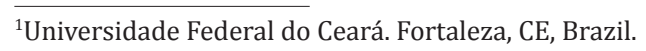




\section{Introduction}

Labor and birth care in Brazil has specific aspects. The technocratic and hegemonic model is responsible for worse results in maternal and perinatal care than those found in other countries with equal or lower socioeconomic development index ${ }^{(1-2)}$.

Thus, the maternal mortality rate in Brazil reached 140 deaths per 100,000 live births in 1990 and even after 17 years, in 2007, the maternal mortality rate was 75 deaths per 100,000 live births, demonstrating that even with reduction of $52 \%$ in this period, maternal mortality rate was still high in the country ${ }^{(3)}$. Since then, there have been movements, organizations and the creation of public policies in pursuit of a more humanized and qualified labor and birth. Among these, there is the Stork Network, launched in 2011, which is a strategy established in the National Health System in order to reduce maternal morbidity and mortality, which is an example of transgression of human rights in Brazil. Through this program, women have assured their right to plan the conception, to receive humanized care during pregnancy, childbirth and postpartum period, and the child has the right to be born safely, have healthy growth and development ${ }^{(4)}$.

Worldwide, the demand for emergency services has increased over the past decades, leading to the need to change the service organization. Thus, screening systems have been designed for identifying the clinical priority of each patient waiting in the service, aiming to facilitate equal access ${ }^{(5)}$. Thus, the network has brought, among the numerous benefits for mother and child, the implementation of the service "Reception with Risk Classification", so that, when pregnant or postpartum women look for emergency service, they can be met according to the complexity of their case. This reception is a marker that allows the guarantee of access and implementation of the principle of equity, since it allows the identification of priorities in the care ${ }^{(4)}$.

The Reception with Risk Classification has important goals, such as evaluating the patient on their arrival to the service, decongesting the emergency unit, reducing the time for medical care and enabling the patient to be seen early, according to the severity of their case $\mathrm{e}^{(4,6)}$.

This is a dynamic process of identifying patients, and the nurse is the professional chosen to perform the Reception with Risk Classification in the obstetric unit, by using qualified listening and critical judgment ${ }^{(7)}$. The instrument used in reception enables classifying patients by colors, indicating the need for care according to the disease and the waiting time ${ }^{(4,8)}$.

The implementation of this Reception System with Risk Classification in obstetric emergency departments of Brazilian hospitals is recent, which reinforces the need to evaluate it. Another country that uses screening performed by obstetric nurses found high satisfaction of patients, especially in relation to the waiting time $\mathrm{e}^{(9)}$.

It is important to note that reception in obstetric emergency departments should have some peculiarities due to the needs related to pregnancy and puerperal process. Anxiety that permeates pregnancy, childbirth and birth leads to insecurity and concern in women and their families. This is mainly due to lack of information during prenatal care, which is one of the factors that contributes to seeking emergency services frequently. Because of this, hosting women and their companions has promotes the empowerment of pregnant women, especially during labor and delivery ${ }^{(7)}$.

Due to the recent insertion of the protocol for Reception with Risk Classification in the obstetric unit of the researched hospital, this study was necessary in order to evaluate the implementation of the Reception with Risk Classification.

\section{Methods}

This is an evaluative research held in an obstetric emergency department of a reference hospital for high-risk pregnancy located in Fortaleza. Data was collected in July 2014. Authors chose this 
hospital because it was the latest institution to implement the Protocol for Reception with Obstetric Risk Classification in Fortaleza in its emergency service. This implementation took place in September 2013, following the principles of the National Humanization Policy/Stork Network Program ${ }^{(9)}$, proposed by the Brazilian Ministry of Health. Based on these principles, the researched institution has prepared an instrument containing the items assessed for patient classification, which were completed in each service. The study population was composed of 736 risk classification instruments filled in the Obstetric Emergency Unit in the first month of its implementation (September 2013). The sample was similar to the population.

The researcher had prepared a form previously, which was used as data collection instrument, seeking information on the arrival time, reception time and medical care time. Data as obstetric profile, vital signs, origin, medication in use, complaint and received classification were also verified.

To organize the data, the researcher used programs such as Excel 2010 and for analysis, the Statistical Package for Social Sciences version 20.0. Data was grouped in charts, graphs or tables, submitted to descriptive analysis with frequency, percentage, average and $95.0 \%$ confidence interval, and analyzed in the light of the literature.

The study complied with the formal requirements contained in the national and international regulatory standards of research involving human beings.

\section{Results}

In September 2013, 736 women were admitted to care in obstetric emergency, 80.1\% ( $n=590)$ sought care spontaneously, $12.8 \% \quad(\mathrm{n}=94)$ were referenced and $7.1 \%(n=52)$ were not recorded. The vast majority came from the capital $(n=609 / 82.7 \%)$; however there was a significant number of patients coming from the interior of Ceará state $(n=1 / 5.5 \%)$, mainly from the following regions: Metropolitan area ( $n=18 / 43.9 \%)$, Maciço do Baturité ( $\mathrm{n}=8 / 19.5 \%)$, Vale do Jaguaribe $(n=6 / 14.6 \%)$, north of the state $(n=5 / 12.2 \%)$, west coast $(n=2 / 4.9 \%)$ and two were not recorded (4.9\%). Among these, the municipalities of Caucaia ( $n=09 / 21.9 \%$ ), in the Metropolitan Region, and Baturité ( $\mathrm{n}=07 / 17.0 \%)$, located in the Maciço do Baturité region stood out.

Regarding the obstetric profile, most women were pregnant $(n=668 / 90.7 \%)$ or in postpartum period ( $\mathrm{n}=19 / 2.6 \%)$ and a small amount could not be identified because there was no record $(n=3 / 0.4 \%)$; however, a great number of women sought care without being in pregnancy and puerperal period $(\mathrm{n}=46 / 6.3 \%)$.

As for parity, there were women with multiple pregnancy $(n=469 / 68.5 \%)$, primiparous women $(n=263 / 38.4 \%)$ and women who had never miscarried ( $\mathrm{n}=524 / 76.5 \%)$. The gestational period in which more women sought care was the third trimester ( $\mathrm{n}=391 / 58.6 \%)$.

Most patients $(n=584 / 87.4 \%)$ did not use any medication during pregnancy. Among those who used $(n=84 / 12.6 \%)$, the vitamin supplement ( $n=73 / 86.9 \%$ ) was the most cited, followed by antihypertensive drugs ( $\mathrm{n}=06 / 7.1 \%)$ and antimicrobials $(\mathrm{n}=03 / 3.5 \%)$.

Of the pregnant women $(n=668)$ seeking care, $83.0 \%(n=555)$ had some symptom and the most mentioned were pain $(n=234 / 42.1 \%)$ and transvaginal bleeding ( $\mathrm{n}=124 / 22.3 \%)$.

Regarding complaints, the most frequent during the third trimester $(\mathrm{n}=314 / 47.0 \%)$ was pain $(\mathrm{n}=87 / 27.7 \%)$, then there were the pregnant women in the first trimester $(n=220 / 32.9 \%)$ with transvaginal bleeding ( $n=52 / 23.6 \%)$.

Still, a percentage of $17.2 \% \quad(n=115)$ of pregnant women in this study were asymptomatic at the time of care; showing test results ( $\mathrm{n}=22 / 19.1 \%)$ and conducting pre-natal care $(n=25 / 21.7 \%)$ were the main motivations for seeking the service.

Puerperal women were the least likely to 
seek the service $(n=19 / 2.6 \%)$. Of these, nearly half ( $n=09 / 47.3 \%$ ) did not show any symptoms at the time of care, but sought the service for removing stitches $(n=06 / 66.6 \%)$ and for examination of the cesarean section $(n=03 / 33.4 \%)$. The other half $(n=10 / 52.7 \%)$ complained about wound complications (infection and bleeding).

The number of women who sought care with complaints not related to pregnancy and puerperal period ( $n=46 / 6.3 \%$ ) was higher than number of puerperal women seen in the obstetric emergency department. These sought the service to show test results ( $n=08 / 17.3 \%)$, ask questions about surgical procedures ( $n=05 / 10.8 \%)$, because of heavy menstrual flow $(n=03 / 6.5 \%)$ and even to perform Pap smear $(\mathrm{n}=02 / 4.3 \%)$.

The patients living in the capital often had symptoms $(n=455 / 74.7 \%)$, but there were cases of asymptomatic pregnant women $(n=92 / 15.1 \%)$ and complaints not related to puerperal and pregnancy status $(n=62 / 10.2 \%)$. Of the patients living in the countryside of the state, most had symptoms ( $n=37 / 90.2 \%$ ) compared to the asymptomatic group ( $n=03 / 7.3 \%)$ and to those who had no complaints related to pregnancy and puerperal status $(n=01 / 2.4 \%)$. The pregnant women living in the countryside of the state and with symptoms lived primarily in the metropolitan area $(n=16 / 45.7 \%)$ and in the Maciço de Baturité region ( $\mathrm{n}=8 / 22.9 \%)$.

In the obstetrical examination, the three most frequently encountered changes, regardless of gestational age, were: absence of fetal movement (34.6\%), transvaginal bleeding (17.5\%) and the presence of uterine contractions $(12.0 \%)$.

Among the 736 (100\%) women treated in the emergency obstetric department during the month of implementation of the protocol for Reception with Risk Classification, there was record of risk classifications of 711 (96.6\%) attendances. These were classified into blue $(n=159 / 22.3 \%)$, green $(n=344 / 48.3 \%)$, yellow $(n=134 / 18.8 \%)$ orange $(n=68 / 9.5 \%)$ and red $(n=06 / 1.1 \%)$.
Table 1 - Distribution of patients according to risk classification and the average waiting time for service

\begin{tabular}{lc}
\hline Classification & $\begin{array}{c}\text { Waiting time (minutes)/ } \\
\text { Average (CI 95\%) }\end{array}$ \\
\hline Red $(n=06 / 1.1 \%)$ & $13.5(6.9-20.0)$ \\
Orange $(n=68 / 9.5 \%)$ & $34.2(26.2-42.1)$ \\
Yellow $(n=134 / 18.8 \%)$ & $39.0(33.7-44.4)$ \\
Green $(n=344 / 48.3 \%)$ & $51.9(47.2-56.5)$ \\
Blue $(n=159 / 22.3 \%)$ & $39.9(33.7-44.4)$ \\
\hline
\end{tabular}

According to the data in Table 1, the average waiting time for all classification was longer than the time recommended by the Brazilian Ministry of Health. However, there was the underreporting of data on waiting time in the service, which is a limitation of the study because it was not possible to analyze this data in all records.

\section{Discussion}

The main limitation of the study was the data source because it is a documantary research. Thus, the is an underreportinh of information, causing some gaps in the research.

According to the results, it was evident the contribution to the service, which is the need for continuous training of professionals working in the risk classification in obstetric area, so that the quality of access to women in pregnancy and puerperal period can be guaranteed.

Thus, when analyzing the risk classification, the majority (47.6\%) of women were classified as not urgent for medical care, receiving the green color as identification (Table 1), corroborating a study on Reception with Classification Risk in a public hospital in Rio de Janeiro in 2012(10). The green classification is considered not urgent, so it has estimated waiting time between sixty and one hundred and twenty minutes, being reevaluated every sixty minutes and conducted to the medical consultation.

By comparing the data obtained from a survey conducted in the emergency services of Sweden, it 
was found that the percentage for the red $(92.0 \%)$ and orange $(91.0 \%)$ classifications were higher than those of yellow color $(66.0 \%)$ and green $(63.0 \%)$ colors $^{(7)}$. This means that the profile of care in obstetric emergency departments of developed countries is characterized by more severe patients who actually require immediate care, different from what is found in Brazil, where most of the visits is due to little urgent causes, reflecting the weakness of primary care, which is responsible for this type of care.

Clearly perceived by the data obtained in this survey, most women classified as high risk (Red and Orange) was not met in a time consistent to their clinical situation, which would be immediate care for the red classification and up to 15 minutes for the orange classification. This fact brings the reflection that the service has flaws regarding attending in the appropriate time and in the record of waiting time for attendance.

This situation is worrisome and worthy of immediate interventions such as raising awareness of professionals regarding the importance of properly recording data as well as the improvement of conditions that prevent the attendance at the appropriate time, such as infrastructure, human resources and service management. Therefore, the structure and support of the maternal and child network must necessarily adopt strategies to ensure access of pregnant women to maternity in appropriate time, providing safer pregnancy ${ }^{(10)}$.

It was observed that many study participants sought care without being in pregnancy and puerperal period, even surpassing the number of puerperal women.

The profile of women who sought care contrasts with a study conducted in 2011 in a public hospital in Rio de Janeiro, Brazil, in which pregnant women accounted for the total of $94 \%$, followed by puerperal women $(4.5 \%)$ and fewer women out of pregnancy and puerperal period $(1.5 \%)^{(10)}$.

The search by these women was justified by the need to show test results, ask questions about surgery, due to heavy menstrual flow and even to perform Pap smear. This fact relates to the misinformation of patients in primary care because such requests could have been solved in the basic health unit.

In following the care for pregnant women, this study found that primiparity stood out as the greatest susceptibility factor to seeking care and the appearance of complications. Interestingly, most were primiparous women who were in the third trimester, and had pain and transvaginal bleeding as the main reported symptoms. In this regard, ignorance and myths surrounding pregnancy, childbirth and birth, together with disinformation in prenatal care lead women to seek emergency service.

Gestational bleeding deserves special attention because it is among the three causes that most kill women in pregnancy and puerperal period ${ }^{(11)}$ and therefore should be investigated. In the context of risk classification, the bleeding patient is at imminent risk of death; therefore, depending on the health status and acute complications, such as hypovolemic shock, the service must be performed immediately ${ }^{(7)}$.

The complaints of patients are consistent with research conducted in a maternity hospital in Rio de Janeiro, Brazil, in 2012, which evaluated 200 women, and of these, $94.0 \%$ were pregnant women, $35.5 \%$ complained of pain and $15.5 \%$ of transvaginal bleeding ${ }^{(10)}$.

On the other hand, it should be noted that $17.2 \%(n=115)$ of pregnant women in this study were asymptomatic at the time of care, and the main motivations for seeking the service were showing test results and performing prenatal consultation. These data show that the search for emergency care has been mischaracterized, causing an increase in demand in the service and, consequently, decrease in the quality of care.

Few women sought care during the postpartum period. The search for the emergency unit aimed at removal of the stitches and review of cesarean section, which indicates lack of information by users. Thus, health professional should address these issues 
during prenatal consultation and discharge from maternity ward.

The interview held in obstetric emergency unit enabled to investigate the use of medications by pregnant women. Most patients reported not using, but a significant percentage used vitamin supplement, anti-hypertensive and anti-microbial drugs. Studies reveal that the use of any medication during pregnancy cannot be indiscriminate because of the potential risks and damage caused by their toxicity to the fetus ${ }^{(12-13)}$. In fact, there is evidence that the greater the use of antibiotics during pregnancy, the greater the change in the heterogeneity of the intestinal flora of newborns and the colonization by certain pathogens ${ }^{(14)}$. The antihypertensive drugs deserve attention because they are related to the treatment of gestational hypertension that increases the risk of perinatal morbidity and mortality ${ }^{(15)}$.

\section{Conclusion}

The analysis of records in the risk classification in an obstetric reference hospital shows the ignorance of the patients on the actual signs and symptoms that characterize an emergency. The data reaffirm the need for further guidance in primary health care services on when women should seek specialized care.

Moreover, this study evaluated the first month of the implementation of the Reception with Risk Classification, indicating the lack of training of professionals both in relation to filling the records and in relation to the classification management.

To conclude, the clientele seeking gynecological and obstetric care needs to be better informed in primary care about the signs and symptoms that characterize emergent and urgent care, because the great and unnecessary demand for this service and the lack of training of professionals working in the obstetric emergency department have led to higher waiting time than the recommended by the Brazilian Ministry of Health.

\section{Collaborations}

Brilhante AF, Vasconcelos CTM, Bezerra RA, Lima SKM, Castro RCMB and Fernandes AFC contributed to the design and development of the project, data collection and analysis, writing and critical analysis of relevant intellectual content and final approval of the version to be published.

\section{References}

1. Dias MAB. Humanização do parto: política pública, comportamento organizacional e ethos profissional. Cad Saúde Pública. 2011; 27(5):1042-3.

2. Secretaria Municipal de Saúde de Fortaleza (CE). Sistema Municipal de Saúde Escola. Protocolo de acolhimento com classificação de risco em obstetrícia. Fortaleza: Secretaria Municipal de Saúde de Fortaleza; 2012.

3. Ministério da Saúde (BR). Secretaria de Vigilância em Saúde. Departamento de Análise de Situação de Saúde. Saúde Brasil 2009: uma análise da situação de saúde e da agenda nacional e internacional de prioridades em saúde. Brasília: Ministério da Saúde; 2010.

4. Ministério da Saúde (BR). Portaria no 1.459 de 24 de junho de 2011. Institui no âmbito do Sistema Único de Saúde - SUS - a Rede Cegonha. Brasília: Ministério da Saúde; 2011.

5. Carmen LMD, Maria ADSL. The nurse's role in Emergency Triage Systems: literature analysis. Online Braz J Nurs [Internet]. 2011 [cited 2016 Mar 13];9:3. Available from: http://www. objnursing.uff.br/index.php/nursing/article/ view/j.1676-285.2010.3132

6. Ministério da Saúde (BR). Secretaria de Atenção à Saúde. Manual prático para implementação da Rede Cegonha. Brasília: Ministério da Saúde; 2011.

7. Paul J, Jordan R, Duty S, Engstrom JL. Improving satisfaction with care and reducing length of stay in an obstetric triage unit using a nursemidwife-managed model of care. J Midwifery Womens Health [Internet]. 2013 [cited 2013 July 10];58(2):175-81. Available from: http://www. ncbi.nlm.nih.gov/pubmed/23489525 
8. Grupo Brasileiro de Acolhimento com Classificação de Risco. História da Classificação de Risco no Brasil [Internet]. 2015 [citado 2016 mai 10]. Disponível em: http://www. gbacr.com.br/index.php?option=com_content\&task=view\&id=75\&Itemid=109

9. Ministério da Saúde (BR). Secretaria de Atenção à Saúde. Manual de Acolhimento e Classificação de Risco em Obstetrícia. Brasília: Ministério da Saúde; 2014.

10. Pereira ALF, Lima AEF. Host with risk classification in a public maternity. Rev Enferm UFPE on line [Internet]. 2014 [citado 2016 mai 10]; 8(supl 1):2309-15. Available from:http://www.revista. ufpe.br/revistaenfermagem/index.php/revista/ article/view/5420/pdf_5657

11. Rezende J, Montenegro CAB. Obstetrícia fundamental. Rio de Janeiro: Guanabara Koogan; 2014.
12. Costa JM, Rocha LM, Santos CM, Abelha LL, Almeida KCA. Análise das Prescrições Medicamentosas em uma Maternidade de Belo Horizonte e Classificação de Riscos na Gestação e Amamentação. Rev Bras Farm Hosp Serv Saúde. 2012; 3(1):32-6.

13. Petersen I, Gilbert R, Evans S, Ridolfi A, Nazareth I. Oral antibiotic prescribing during pregnancy in primary care: UK population-based study. J Antimicrob Chemother. 2010; 65(10):2238-46.

14. Fritzen JS, Colet CF, Oliveira KR. Uso de antimicrobianos por gestantes no serviço público de saúde. Rev Bras Promoç Saúde. 2014; 27(2):198-206.

15. Souza AR, Amorim MR, Costa AR, Neto CN. Tratamento anti-hipertensivo na gravidez. Act Med Port. 2010; 23(1):77-84. 